\title{
Blow Up \\ imagens e miragens
}

PAULO MENEZES

\author{
Para o Bruni, meu amigo, com quem \\ aprendi a perceber e a enfrentar os \\ complexos dilemas do pensamento
}

RESUMO: Este artigo analisa o filme Blow Up de Michelangelo Antonioni, buscando compreender como o seu discurso visual questiona a relação entre real e imaginário. Por trás de um crime do qual nada sabemos e nada saberemos, a busca efetuada pelo fotógrafo levanta e problematiza as relações entre as imagens e as coisas, sejam elas fotografias ou filmes, propondo significados para seus fundamentos e perspectivas que muito os afastam das interpretações que as colocam como reproduções ou representações de um real pressuposto como íntegro e preexistente.

PALAVRAS-CHAVE:

Blow up,

Antonioni, imagem, real, fotografia.

Este texto tem por base o primeiro capítulo de tese de doutoramento orientada por Bruni.

Paulo Menezes foi orientando de José Carlos Bruni e continua seu trabalho na editoria de Tempo Social 
avançam em nossa direção, até abrirem-se em toda a dimensão da tela, mostrando, pela única vez, a imagem completa que estava escondida ali por trás e que, ao mesmo tempo que se faz mostrar, desaparece imediatamente sob o fundo das letras seguintes que dominam novamente a tela. Sabendo que algo lá existe, passamos a tentar enxergar detidamente as imagens que nos são negadas a perceber. Para deixar isto ainda mais instigante, a única imagem que pudemos vislumbrar, ainda que por frações de segundo, era a de uma moça que tirava as peças de sua roupa, em cima de um telhado. Pudemos acompanhar apenas seções de seus movimentos, que nos permitiram imaginar o que ela fazia, ao mesmo tempo que esta imagem parecia querer escapar, o tempo todo, por entre nossos dedos, em um estranho movimento que, ao parecer mostrar, acaba efetivamente por negar. Perfeita metáfora, veremos que a proposta que engendrava não era de forma alguma inocente.

As primeiras imagens que nos são realmente dadas a ver nos jogam novamente em um mundo de incongruências. Montados sobre um jeep Land Rover, uma imensa trupe de mímicos agita-se vigorosamente, mãos e pernas saltando pelo ar, acompanhados pelos gritos efusivos que emitem sem parar. Isto contrasta, de maneira cortante, com o fato de, em geral, a mímica ser um dos lugares primordiais do seu oposto, o silêncio. $\mathrm{O}$ local pelo qual passam não é menos peculiar. Nada vemos ali, nenhum tipo de movimento, nenhuma pessoa a não ser o jeep, que anda pelo meio dos prédios, todos vazios e sem qualquer sinal de vida. Perfeito cenário para um grupo a um só tempo mudo e barulhento, que só irá adquirir o seu mais profundo significado quando, circularmente, reaparecer na cena final do filme.

O surgimento de nosso personagem principal, um fotógrafo de moda, será também bastante inesperado. Ele aparece no meio de um grupo imenso de pessoas, com roupas velhas e desalinhadas, que sai de um estranho local, parecido com uma grande fábrica - somente muito depois, no momento em que ele mostra as fotos que lá havia tirado ao editor do livro que prepara, saberemos que se trata de um albergue de mendigos e de pessoas que não têm outro lugar para dormir, os despossuídos mas também súditos do grande reino, mesmo que já não tão grande.

Detalhes da sua relação com o mundo que o cerca já nos são apresentados desde a primeira cena. De dentro do carro, por meio de um radiotransmissor, ele começa a dar ordens a várias pessoas. Quando chega

Aqui, no Brasil, a criatividade em mudar nomes de filmes é realmente espantosa. Este filme de Antonioni recebeu entre nós o nome absurdo de "Depois Daquele Beijo". Nas fitas de vídeo, para não perder a referência de um público não especializado, juntou-se os dois. ao ateliê, distribui uma série de serviços aos seus auxiliares, de uma maneira fria e automática. No instante em que Thomas entra no estúdio, vemos a modelo que já o esperava há algum tempo. Mas não a vemos diretamente. Vemos apenas seu reflexo por meio de um espelho que parece estar ali jogado ao acaso. Ela aparece para nós como aparecerá para ele: como pura imagem, a ser investigada e conquistada. A moça, no momento em que o vê, ensaia uma reclamação "- por estar esperando há uma hora e ter um avião para pegar e não poder...”. “- Can't what?", corta-a Thomas abruptamente, sem lhe dar a menor atenção. Sem muita ação, coloca-se em frente a um fundo infinito escuro, que contrasta com a sua pele muito clara. 
Seu vestido é preto, entremeado de reflexos brancos brilhantes que acompanham seus movimentos, com suas duas laterais abertas, apenas levemente trespassadas por alguns fios que ligam sua frente às costas, $\mathrm{e}$ que, ao mesmo tempo, deixam à vista toda a lateral nua de seu corpo, fino $\mathrm{e}$ comprido, insinuando-se através deles. A relação que se trava em seguida é muito significativa. Thomas, após tirar as primeiras fotos, bebe um copo de vinho e troca a máquina 6x6 que utilizava por uma 35, com lente 50mm, a lente que mais aproxima o que se vê através dela com o campo de visão normal que os olhos contemplam ${ }^{2}$. Ela vai permitir uma maior aproximação entre eles além de mostrar-se a lente perfeita para o que veremos a seguir.

A modelo deita-se pelo chão, exibindo-se e insinuando-se preguiçosamente em suas contorções sonolentas. Thomas vai abaixando-se sobre o seu corpo, até ajoelhar-se sobre ela e encaixar-se sobre seu ventre, em um momento de extrema volúpia visual. Ele a beija ligeiramente no pescoço, visando descontraí-la ainda mais, e, a partir de então, vemos os vários movimentos cadenciados que os seus corpos circunscrevem no espaço, finalizados em um instante de máxima excitação quando Thomas começa a gritar de maneira resoluta e inconfundível: - Yes, Yes, Yes, terminando sua sessão de fotos por meio de um clímax absolutamente visual e inquestionável. Este orgasmo também desdobra-se visualmente na modelo, que continua ali deitada pelo chão, passando suavemente a mão sobre seus seios, até jogar os braços para trás e ficar ali descansando, extasiada ela também com o ato que acabaram de finalizar. Thomas, por sua vez, ao terminar, retira a máquina fotográfica do pescoço, levanta-se, e vai jogar-se sobre um sofá, colocando displicentemente o pé sobre a mesa de centro, de vidro. Acabou de nos mostrar, sem mediações, a possibilidade de transformar em atividade física visual direta a capacidade de penetração que o aparato fotográfico porta em si mesmo ${ }^{3}$.

Ele trata as outras modelos com a mesma distância e arrogância. Organiza as suas posições, reclama com o chiclete que uma delas masca, grita bruscamente com outra que não conseguia sorrir. Por fim, ordena a todas que fechem seus olhos e relaxem, enquanto ele, simplesmente, vai embora, fazer outra coisa.

Seus relacionamentos são todos assim, permeados por um filtro que, ao mesmo tempo que permite uma espécie de ligação, mantém inexoravelmente presente uma intransponível distância.

Os únicos momentos em que o vemos aparentemente mais ligado afetivamente a alguém, demonstrando uma atitude mais carinhosa e reveladora, são aqueles em que está em companhia da mulher que mora com um pintor, em uma casa ao lado do ateliê. Em um primeiro momento, após conversar de maneira distraída com Bill sobre as suas pinturas, sentase em uma poltrona enquanto ela, após pegar uma garrafa de cerveja para lhe oferecer, passa a mão em seus cabelos começando a massagear-lhe a cabeça. Seu olhar está cabisbaixo e triste, mostrando-nos que, afinal, ali reside alguma sensibilidade, mesmo que escondida. No momento em que ele se levanta e sai, deixa-a sozinha, com o olhar perdido ao longe.

$\mathrm{O}$ segundo momento ocorre quando, após o roubo das fotos em
${ }^{2}$ Que é de aproximadamente $60^{\circ}$ (cf. Langford, 1974, p. 87).

${ }^{3}$ Cartier Bresson dizia que o fotógrafo, com a máquina na mão, sempre age como se perpetrasse um crime, o que não deixa de ser uma forma de violação. A palavra fotografar, em inglês, não deixa dúvidas - to shoot significa atirar, matar, aplicar injeção, mas também fotografar e filmar. 
4 Uma delas é Jane Birkin, que ficaria mundialmente famosa alguns anos depois, ao cantar com o seu maridoSerge Gainsborough uma música que seria proibida em vários países do mundo, incluindo-se aí o Brasil, pela sua sonoridade que "imitava" (?) os barulhos de um ato sexual: Je t'aime. seu estúdio, Thomas retorna novamente até o seu vizinho. Ao entrar sem bater, caminha pelo corredor até olhar pela porta de um quarto. Seus olhos encontram-se com os dela, dessa mulher nunca nomeada, olhando-o com uma expressão de extremo incômodo, enquanto vemos Bill movimentar-se sobre seu corpo sem nada perceber. Momentos após, ela vai encontrá-lo no estúdio. Thomas pergunta-lhe se nunca pensou em deixá-lo, recebendo a resposta negativa. Entretanto, um pouco depois, ela vai lhe pedir que a ajude. Quando ele pergunta no quê poderia ajudá-la, ela volta a falar sobre o crime, desconversando. Em todos os momentos em que se encontram, nunca conseguem falar sobre eles, sobre suas vidas, sobre o que sentem, sobre o óbvio.

O momento mais emblemático da relação de Thomas com as coisas e com o mundo que o cerca é aquele dos encontros que vai ter com duas mocinhas ${ }^{4}$ que vão até o estúdio, na esperança e na vontade de serem "fotografadas" por ele. Seu primeiro encontro é extremamente significativo: pedem-lhe dois minutos para conversar enquanto ele, sentado na cadeira de sua secretária, diz-lhes, com uma expressão impassível que denota ao mesmo tempo um certo menosprezo, que não tem dois minutos nem mesmo para tirar o apêndice fora. Seu ar é sempre esse, de senhor do mundo, a um só tempo superior, prepotente e arrogante.

Em seu segundo encontro com elas, quando está no meio da revelação das fotos do parque, sua postura em nada se altera. Thomas ouve um barulho na porta da frente. Desce para abri-la mas, percebendo um movimento diferente lá fora, apenas vira de costas, levanta a ponta do pé, aguarda alguns segundos para então, suavemente, escorregar a mão sobre a maçaneta deixando que a porta se abra de repente, e de uma só vez. Uma das garotas que ali se apoiava tropeça, caindo de costas para dentro do ateliê, com o olhar assustado. Sua amiga, que entra em seguida, perguntalhe o óbvio: “- Você não estava nos esperando, estava?". As duas têm um ar engraçado e displicente. Seus cabelos têm o mesmo corte, liso, caído, com aquela franjinha "anos 60" que escondia praticamente toda a testa. Seus vestidos são dois tubinhos muito justos, ambos tendo o azul como cor predominante. Uma delas veste meias amarelo-claro, combinando com a cor da barra do vestido. A outra, meias vermelho-claro. Esta usa, além disso, um sapato também vermelho, com listas coloridas. A outra, um sapato azul com enormes bolas amarelas. Os dois envernizados e brilhantes.

Sobem rapidamente, e logo sentem-se atraídas pela enorme quantidade de vestidos que descansam em uma arara de uma das salas do estúdio. Começam a mexer em todos eles, enquanto a mais alta (Birkin) logo começa a retirar o seu. Deixa-o cair ao chão, e a vemos de costas, com uma meia calça que lhe cobre a cintura, começando a experimentar um deles. O que vemos a seguir é uma cena pitoresca. Thomas entra na sala subitamente. Ela, que está com um vestido de alças ainda aberto nas costas, encolhe-se toda. A amiga foge ao ouvir o barulho da cafeteira, deixando-os sozinhos. Colocando seus dedos na alça do vestido, Thomas o arranca enquanto ela o encara com um olhar misto de vergonha e entusiasmo. Ela agarra seu antigo vestido e com ele protege os seios desnudos, escondendo- 
se atrás do cabideiro. Sem pestanejar, nosso fotógrafo joga o cabideiro no chão, pisa em cima dos vestidos e vai em sua direção. Esta atitude marca de maneira indelével a diferença intransponível entre eles. Elas estão embevecidas por aqueles vestidos, que as atraem completamente, enquanto ele, não só não lhes dá a menor importância, como além de tudo pisa sobre eles para chegar até ela. Não se importa com os vestidos, e, no limite, nem mesmo se importa o mínimo com elas.

Thomas aproxima-se, enquanto Jane Birkin encolhe-se com os braços cruzados no peito perto da porta, e arranca-lhe das mãos este outro vestido com o qual se protegia. Ela finge em seu rosto um certo ar acanhado, alternando sorrisos contidos com uma aparente surpresa pelo jeito atirado do até então ascético fotógrafo. Ele coloca a mão em seus cabelos; ela morde o seu pulso. Sinal inequívoco de que os toques foram autorizados. Começam uma luta: ela grita, ele ri, e nós ficamos na dúvida se ela se defende de verdade ou se está apenas e tão somente fazendo um certo charme no jogo sempre complexo da sedução, quando dizemos não no momento em que na verdade queremos dizer $\operatorname{sim}^{5}$. A resposta a esta dúvida vem logo a seguir. A amiga, ouvindo a gritaria, vem correndo da cozinha e, ao perguntar o que está acontecendo, surpreende-se com a outra que se joga sobre ela, oferecendo-a a Thomas, alegando que ela possuía um corpo mais bonito, ao mesmo tempo em que começa, ela mesma, a arrancar-lhe todas as roupas. Ambas rolam pelo chão, tentando se despir, e depois correm para o estúdio onde desenrolam o fundo infinito lilás por todo o chão. Jogamse sobre ele enquanto finalmente se despem, sempre gritando e batendo os pés, numa grande algazarra. Thomas entra finalmente na "dança" e as duas aproveitam para também despi-lo. Quer dizer, pressupomos que o despem, pois a cena é cortada abruptamente neste momento, enquanto ele ainda está de calças, e, no momento em que retorna, todo o barulho já acabou e apenas vemos o fundo infinito todo amassado, para que só depois nos sejam mostrados os três. Porém, neste momento, elas já estão totalmente vestidas e terminando de vesti-lo também. Ele ainda está deitado de costas, tendo cada uma das garotas ajoelhadas literalmente a seus pés, colocando-lhe delicadamente as meias, num momento da mais completa e absoluta submissão, que não deixa dúvidas sobre as intenções da relação que travaram com o fotógrafo e, ao mesmo tempo, sobre a (des)importância que ele mesmo deu a esta relação.

Seu olhar, antes perdido no teto, passa pelo meio delas para atingir as fotos penduradas que atraem, magneticamente, de novo toda a sua atenção. Thomas levanta-se - uma delas começa a vestir-lhe a camisa - e passa entre as meninas como se elas nem estivessem mais por ali. Quando as duas se espantam com o fato de ele as mandar embora, sem tirar ao menos uma foto, sua resposta é, ao mesmo tempo, emblemática e sintomática: "- estou muito molhado". Ao perceber que ambas olharam-se com o rosto espantado e um pouco atônito, ele termina por arrematar: “- E a culpa é de vocês".

Esta cena de orgia, pressuposta e não-visível, apesar de parecer ter sido absolutamente pueril, foi, ao mesmo tempo e por mais estranho que
5 Simmel, ao tratar do erotismo como uma forma de sociabilidade, afirma: "A natureza da coqueteria feminina é jogar alternativamente com promessas e retraimentos alusivos para atrair o homem, mas para deter-se sempre antes de uma decisão, e para rejeitá-lo, mas nunca privá-lo inteiramente da esperança.(...)Seu comportamento oscila entre o "sim" e o "não", sem fixar-se em nenhum deles" (Simmel, 1983, p.174-175). É óbvio que no momento em que a relação sexual se concretiza este jogo perde o seu sentido inicial. 
${ }^{6}$ Aos olhos de hoje, obviamente. Na época, considerada muito ousada, recebeu a te-soura dos censores em vários países (cf. Vogel, 1974, p. 215).

${ }^{7}$ E evidente que sabemos que este "acaso" foi absolutamente intencional, pelo menos por parte das meninas, que esperavam com isso abrir as portas para a sessão de fotos, com interesses mais do que evidentes. No caso do fotógrafo, que é o que nos interessa, elas simplesmente surgiram do nada em seu es-túdio, o que é o importante para o racio-cínio que estamos desenvolvendo.

${ }^{8}$ Sobre o compartilhamento de sentidos na constituição de relações sociais cf. Weber (1978). isso possa parecer nos dias de hoje, bastante inovadora, por ter apresentado pela primeira vez, mesmo que apenas de relance, os pêlos púbicos de uma mulher nas telas do cinema comercial, de grande público ${ }^{6}$. Mas, o que é significativo para nosso argumento é o jeito totalmente casual no qual ela começa, transcorre, e acaba. Além de que, ao mesmo tempo em que é uma relação coletiva totalmente "ao acaso" entre pessoas que não se conhecem, é também uma bela mostra de uma relação sexual sem qualquer tipo de envolvimento e que acaba da mesma maneira como começou, escoando pela porta do estúdio fotográfico ${ }^{7}$. Isto nos mostra de maneira muito clara que a ligação de Thomas com o mundo se faz, primordialmente, pelos olhos das lentes fotográficas de suas máquinas. Quando lhe falta esta mediação, ele sempre age de uma maneira distante, fria e deslocada, sem envolvimento evidente, sem dar a isso qualquer significado, e, consequientemente, sem constituir algo que possa criteriosamente ser chamado de "relação"». É apenas a sua máquina que lhe permite colocar-se nas coisas e conseguir participar delas de uma maneira incisiva e decisiva.

Thomas comunica-se com todo mundo e durante todo o filme. Mas sempre desta maneira exterior, como se não fosse ele e nem com ele, ou como se ele mesmo não estivesse lá. Em apenas dois momentos toma realmente a iniciativa de se comunicar, sem obter qualquer resultado. São os momentos que se seguem ao roubo das fotos em seu estúdio: quando está com a mulher do pintor, como vimos, e quando está na festa no final do filme, tentando falar com seu editor. Voltaremos a este assunto mais à frente.

Blow Up é um filme repleto destes momentos onde parece que todo mundo fala línguas diferentes. Ou, onde parece que todo mundo fala a mesma língua mas que mesmo assim ninguém se entende.

As cenas que ocorrem no antiquário são disto exemplares. Primeiro, com o velho empregado, que parece parte viva do que deveria estar vendendo. No momento em que vê Thomas pela primeira vez, diz-lhe que não existe nada lá que seja barato e que ele está, portanto, perdendo tempo. Perguntalhe o que procura, para então dizer que lá não existem pinturas para serem vendidas. Quando Thomas mostra-lhe algumas, o empregado pergunta de que tipo são as que procura. À sua resposta de que quer paisagens, ele responde que não as tem. Por fim, quando encontra uma paisagem, diz que aquela já está vendida, que todas estão vendidas. Nada do que Thomas diz retira o vendedor desta posição de recusa. É um vendedor que só faz o contrário do que dele se espera, pois nunca vende nada. E que, ainda pior, espanta com o seu jeito "sutil" todos os possíveis fregueses.

Quando o fotógrafo volta à loja, para falar com a proprietária, uma jovem sorridente com o olhar a um só tempo sonhador e distante, esta lhe diz que quer vender a loja pois está cansada de antigüidades. Que gostaria de fazer algo diferente... "- viajar para o Nepal". Quando ele lhe diz que o Nepal é só antigüidades, ela se espanta e diz, com o olhar compenetrado, que então deveria tentar... Marrocos. Thomas sorri, e olha para baixo com cara de que aquilo não tem jeito mesmo. Quando vê uma enorme hélice e pede para saber seu preço, a moça faz um ar de não ter a menor idéia e, após pensar um pouco, acaba por dizer 8 libras. 
Parece, na verdade, que ela não tem a menor idéia das coisas e do mundo que a cerca. Mundo este onde as coisas se trocam uma pelas outras por meio das imagens (de)formadas que se fazem delas. $\mathrm{O}$ antiquário é um lugar sintomático e significativo disto, pois acumula uma série de objetos diferentes, cada um repleto de sua própria história, mas todos retirados de seu tempo e espaço, que dariam as referências e o sentido à vida que recobrem e que podem desvelar ou revelar. Esta loja é apenas um empilhamento de coisas que, só por estarem juntas, não portam nenhum sentido particular. É apenas um lugar onde se vasculha um monte de objetos para se tentar encontrar alguma coisa interessante, interessante para nós. Como as fotos tiradas ao acaso no meio do parque, imagens sem sentido procurando reencontrar seu significado no fluxo do tempo e do espaço, no fluxo da vida, de alguma vida, seja ela qual for. Ao serem recolocados em um fluxo qualquer de tempo, ao recuperarem a referência de seu lugar na história, ou sua referência em uma outra história, recuperam também sua identidade como objetos e se reencontram finalmente com o seu tempo reinserido no tempo presente. São, por fim, o seu presente de então, que emerge no presente de hoje. Se isto não acontece, restam apenas como um monte de objetos perdidos no meio do tempo do presente e largados em um espaço qualquer, restos de um dia perdido no escoar complexo do tempo e da memória9.

Uma outra idéia aqui reforça-se de maneira irrefutável: de que neste filme, Antonioni constrói as suas mulheres sempre como personagens sem vontades, confusas e aparentemente imbecis. São meras imagens que alternam de maneira nem sempre sutil os seus conteúdos: nunca sabem o que querem (como a vizinha e a dona da loja de antigüidades), ou são puro corpo destituído de ação (como as modelos), ou acham que estão conseguindo o que querem sem se dar conta da inutilidade de seus esforços (como as duas do ateliê e também a que vai buscar o filme). Todas mostram-se fúteis, nas vontades ou nos motivos, na forma pela qual vêem e se inserem no mundo: pelos vestidos, pelo marido pintor, pelos "nepais" e pelos "marrocos". Não sabem o que querem e quando sabem nada conseguem. Não sabem para onde vão. Não possuem identidade própria nem nada que as distingam uma das outras. Nenhuma delas nem ao menos tem nome. São "pessoas" que se misturam e se reduzem às coisas que as envolvem, aos espaços nos quais se encontram. São manchas a confundir ainda mais a marcha dos acontecimentos. São aparições desconexas no fluxo dos acontecimentos que desviam nosso herói da busca incessante de sentido. São duplos dos quadros de Bill, onde em princípio nada se vê, e onde, com alguma sorte, pode-se olhar bem e por fim encontrar alguma coisa que tenha algum sentido no meio de tantos borrões. Mas que nunca se encontra. Parecem ser a expressão fugaz da ausência de conteúdo, a materialização objetual de um grande vazio, a recorrência incessante e inexorável de sua redução a menos do que nada. Com apenas uma pequena exceção: a personagem vivida por Vanessa Redgrave. Ela é a única que parece apresentar alguma vontade ao mesmo tempo que demonstra saber o que faz e o que quer, por mais que, mesmo para ela, as coisas nunca saiam do jeito esperado. Além de que, ela

9 Sobre isso consulte Benjamin (1994a; 1994b) e Deleuze (1985). 
também, como as outras, vem assim como vai, sem deixar rastros ou pistas. $\mathrm{O}$ tradutor brasileiro, ao nomear o filme como Depois Daquele Beijo, remete nossa atenção para o que deveria ser o tema central de sua história: o suspense sobre o que teria acontecido depois de algum beijo, ou seja, depois do beijo no parque, e que seria a morte misteriosa de um homem também misterioso, sobre o qual não sabemos e nunca saberemos nada. É claro que este "enredo" não demora por se dissipar, mesmo que permaneça como pano de fundo da história que vemos até o seu fim. Mas, seus fundamentos são curiosos e escassos. Nada sabemos sobre os seus personagens, por mais que um deles participe de uma longa cena com o fotógrafo. Terminamos o filme sem nada saber sobre a mulher do parque, nem nada sobre o morto. Quem eles são, porque se escondiam, porque ele foi assassinado, porque ela tem tanto medo, de onde ela veio, para onde ela foi, todas são perguntas às quais o filme nega sucessivamente as respostas. Aquela moça viveu uma história que não nos é dada a conhecer, e que, portanto, não pode nos servir como referencial. O mistério que envolve aqueles dois namorados permanece sem solução e não se dissipa até o fim do filme. Quem ficar preocupado com o que aconteceu depois daquele beijo, não deixará de ir embora frustrado do cinema, da mesma forma que ficaram aqueles que esperaram de Hitchcock explicações sobre as razões e os porquês dos ataques de seus pássaros. $\mathrm{O}$ beijo e seus protagonistas não vêm de lugar nenhum e não vão para parte alguma. Eles desaparecem dispersos pelo vento do parque no qual tudo que não podemos compreender aconteceu. Devemos, portanto, olhar em outra direção para tentarmos desvelar o que as imagens que vemos incessantemente nos negam.

A pista crucial do que é de fato a nossa história, e do que deveria estar atraindo decididamente a nossa atenção, nos é dada a conhecer logo nos momentos iniciais do filme. Thomas vai para a casa que existe ao lado do estúdio e lá encontra-se com o pintor, que está olhando para uma tela que pinta há 6 anos. É um quadro cubista, parecido com os que Picasso fazia entre 1911 e 1912, no penúltimo momento de seu cubismo. É o momento em que, passada a fase da decomposição, onde os objetos ainda são, mesmo que dificilmente, reconhecíveis, seus experimentos levam-no a um desmembramento tão brutal que nada mais de concreto podemos reconhecer na imagem que vemos do que apenas alguns de seus detalhes, que podem conformar algum elemento que se assemelhe a algo que por ventura possamos conhecer ${ }^{10}$. Nosso pintor, entretanto, parece seguir o caminho oposto àqueles de seus predecessores. Olha para o quadro, dizendo que aquelas imagens nada significam para ele enquanto as pinta: são apenas uma grande confusão. Explica que depois se retém em algum detalhe, que lhe parece algo. A partir de então, é como se a pintura adquirisse vida própria. Ela mesma se resolveria, se acrescentaria. "-E como achar uma pista em uma história de detetives".

${ }^{10}$ Sobre o cubismo cf. Menezes (1997, especialmente p. 130-135 e 178-186), Golding (1968), Ashton (1985) e Stangos (1981), entre outros.
Sobre o chão de sua casa encontra-se outra de suas pinturas, esta aqui mais na chave de um expressionismo abstrato à la Jackson Pollock. Pingos e mais pingos sobre a tela. De várias cores. Aquele pintor, na verdade, acabou de nos dar todos os indícios que precisávamos para entender do que se trata a nossa história. Mesmo que ele não nos dê quaisquer pistas sobre os seus 
próprios atos. Suas pinturas não são para vender como não existem também para serem dadas. Ele as faz apenas como um detalhe de uma busca pessoal que só para ele mesmo vai ter algum significado, como veremos ser também a busca de Thomas por meio de suas fotos e do que elas revelam, durante todo o decorrer do filme.

Toda a história vai desenvolver-se a partir de um episódio banal, que ocorre completamente por acaso. Na verdade, e o que é mais significativo, ocorre sem que ele mesmo se dê conta, no momento em que passeia por um parque, situado em uma zona de renovação urbana de Londres, que Thomas identifica por três sinais exteriores, alguns especialmente curiosos. Ao sair com o seu carro para ir até o antiquário, ele atravessa uma série de lugares por onde podemos ver os tradicionais exemplos da arquitetura antiga de Londres. Ao virar uma esquina, vemos uma chaminé e blocos de prédios baixos de apartamentos, com arquitetura recente, além de um trator em movimento, o que demonstra estarem estes conjuntos em fase final de construção. O terreno que ocupam ainda apresenta uma parte vazia, cheia de entulhos, que termina na lateral cortada de uma casa. Isto nos mostra que as antigas construções foram derrubadas, para dar lugar ao novo que se ergue. Os outros dois sinais que ele aponta são os mais peculiares. O primeiro, é o de uma mãe com seu carrinho de bebê que atravessa a rua para ir até o parque, o que demostra a instalação nos arredores de jovens casais em começo de vida. O outro, evidentemente preconceituoso, refere-se a dois homossexuais que passeiam pela rua, acompanhados de dois poodles brancos, que Thomas encara de maneira tão exacerbada no momento em que vai entrar no antiquário, a ponto de um deles terminar encarando-o rudemente de volta.

Ao sair da loja, com sua máquina fotográfica, caminha em direção a um parque que está ali ao lado. Ouvimos, desde o instante em que sai dela, o intenso farfalhar nas árvores que se movem ao vento. Passa ao lado de uma quadra de tênis, que irá adquirir um outro e diferente significado no final do filme. O parque parece ser vasto, com poucas pessoas a passear, o que reforça a sensação de seu duplo isolamento, do parque e do fotógrafo. No momento em que fotografa algumas pombas que estão sobre um gramado, vê um casal subindo para a parte mais alta do parque. Vai atrás deles, curioso, para encontrá-los, lá em cima, em um amplo espaço onde estão totalmente sós, acompanhados apenas pelo barulho do vento e das folhas, e pelo olhar indiscreto do fotógrafo, é claro. Esconde-se atrás de uma cerca, esquiva-se para trás das árvores, ajoelha-se no chão. O casal se dá as mãos, gira, brinca, beija-se, abraça-se. Mas, de repente, a mulher o vê e sai correndo atrás dele. Thomas continua a fotografá-la, o que a deixa ainda mais nervosa. Pede o filme, diz que pagaria por ele, mas que o quer agora, e, para conseguir isso, agarra sua máquina e até morde a sua mão. Isto nos mostra que ele deve ter fotografado algo muito importante, algo que não deveria. Um caso proibido de pessoas famosas, apesar de desconhecidas para ele, talvez. A reação da mulher é sintomática de que algo que deveria permanecer escondido estava sendo exposto. É curioso que a mulher argumenta em sua defesa, como fundamento de sua privacidade, o fato de 
estarem em um lugar público, onde as pessoas deveriam ter paz, mas que, teoricamente, é justamente um dos lugares menos privados do mundo, por estar à vista de quem estiver por lá. Talvez, por isso mesmo, às vezes possa ser também o melhor deles para se esconder. A expressão final de seu rosto é a mostra de seu temor, pois ela continua ofegante e apavorada quando lhe afirma que eles nunca se encontraram, que ele nunca a viu. Ao olhar para o lado e perceber que o seu companheiro não está mais lá, corre de novo atravessando todo o gramado. Pára, lá ao fundo, perto de uma árvore, enquanto Thomas continua a fotografá-la não dando muita importância a todo o seu transtorno. Após esta breve parada, ela continua correndo para o fim do parque por onde desaparece. Ficamos ainda alguns segundos a olhar o parque vazio, silencioso, com suas árvores, seus arbustos, suas cercas, e a ouvir o forte barulho do vento a balançar a copa das árvores. Esta imagem final, na qual nada vislumbramos de essencial, será o local de uma série de descobertas fundamentais, que nem ele mesmo ainda percebeu ter sido testemunha. $\mathrm{Na}$ verdade, ele não foi mesmo testemunha de nada, como veremos.

A confirmação de que ele deve ter visto algo que não devia vem do fato de que Thomas passa a ser seguido a partir do momento em que deixa o parque. Enquanto está no restaurante conversando com o editor de seu livro - um livro de ensaio fotográfico sobre a Londres que ninguém quer ver, a dos pobres e desabrigados - alguém começa a mexer em seu carro. Quando ele vai embora, vemos um carro que o segue. E, quando chega na porta de sua casa, ao entrar, dá de cara com a misteriosa mulher que estava no parque, o que aumenta ainda mais a sensação da importância e de desconserto do que ele deve ter fotografado. Vanessa Redgrave mantém o mistério até o fim. Entra com Thomas, sobe para sua sala, olha assustada para todos os lados enquanto ele continua com o seu ar impassível de sempre, como se nunca nada estivesse acontecendo, ou como se nunca as coisas estivessem acontecendo com ele e à sua volta. À apreensão da moça que, em sua única revelação, diz-lhe que sua "- vida está uma bagunça e que seria um desastre se...”, ele responde com o seu tradicional: “-E daí? ...Nada como um pequeno desastre para arrumar as coisas". Ela anda de um lado para o outro, extravasando o nervosismo que não consegue controlar. Ele desconversa com um papo sobre querer fotografá-la como modelo, pedindo a ela que se sente no sofá ao seu lado. Toca o telefone. Ele espera, espera, espera, e, de repente, atira-se pelo chão procurando o aparelho. Atende, e o passa para ela dizendo que a chamam, dizendo depois que é a sua própria esposa. Seu jeito é sempre o mesmo. Indireto, desconcertante, parecendo sempre estar em um registro diferente dos outros. Suas atitudes nos colocam sempre em uma outra dimensão de discurso que parecemos nunca conseguir atingir. Referências diferentes parecem fazer com que as falas não encontrem um lugar comum de troca de experiências. Sua conversa sobre a mulher que estaria falando ao telefone é a expressão deste deslocamento. Fala, e desmente, a cada passo, as informações que ele próprio dá de si mesmo. "É minha mulher. Não, não é. Apenas tivemos alguns filhos juntos... Não, não tivemos, nem mesmo filhos. É como se tivéssemos tido filhos. Ela é 
fácil de conviver... Não, não é. Se fosse fácil, viveria com ela". Ele parece não se comunicar com clareza através das palavras nem consigo mesmo. Não é o seu instrumento de comunicação preferido, nem o que ele controla melhor. Este seu jeito explosivo de fazer as coisas, que confunde os outros, é a curiosa expressão da transposição, para as imagens que vemos da sua vida, de uma outra forma de comunicação que não se dá pelo discurso direto, mas por bits de informação. Se isolados, estes não contém nenhuma informação utilizável. Mas, ao serem reunidos, de uma maneira e ordem conveniente, podem adquirir uma dimensão reveladora essencial.

Esta incompreensão faz com que a moça, irritada também com a demora em resolver o assunto que a levou até lá, pergunte-lhe porque ele não diz logo o que quer, enquanto tenta interpretar os seus desejos começando a tirar a sua camisa, escondendo-se por trás de um monte de plumas, com o rosto fechado e bravo. O fotógrafo, por sua vez, mantém o seu olhar de sempre, virando a cabeça lentamente enquanto levanta a sobrancelha e sorri levemente em tom de deboche, sua postura mais característica. Caminha em sua direção, acariciando gentilmente o seu braço esquerdo e..., mandaa se vestir pois vai lhe devolver o filme. Quando sai da câmara escura, apenas pode ver sua perna que surge como uma aparição por trás do fundo infinito lilás. Esta perna é um convite, que ele aceita ao passar por trás do papel e a encontrar recostada na parede, esperando, pelo filme, e por ele. Uma música suave surge ao fundo, vinda de uma vitrola, sendo uma das poucas que ouvimos no filme, e que contrasta com o som quase totalmente naturalista ${ }^{11}$ que envolve toda a história ${ }^{12}$. Seus braços estão cruzados sobre o peito a esconder o que, ao mesmo tempo, se oferece. Seu olhar agora é meigo, suavemente convidativo. É evidente que, mais uma vez, Thomas não vai fazer o que dele se espera, pois acaba por trocar o filme dando a ela um outro qualquer. As atitudes que executa exigem que seus atos sejam lidos sempre em outra direção do que aparentam mostrar. Ela recebe o filme, pensa um pouco, e vira-se, deixando à mostra docemente seus seios, com o lenço de pescoço que passa levemente entre eles. Voltando-se em sua direção e passando a mão em seus lábios, dá-lhe um beijo suave. Após um outro beijo, mais demorado, encaminham-se para o quarto. O filme, tão procurado e desejado, é jogado displicentemente sobre a camisa que ela vestia. Mas, mais uma vez, o acaso interpõe-se em sua vida pois ouvem a campainha que toca. Eles interrompem aquela relação, que ainda nem havia de fato começado, para receber a hélice que havia comprado naquela estranha manhã. Após este interlúdio forçado, ambos tentam retomar o que estavam fazendo. A mulher senta-se novamente, com o olhar terno e finalmente relaxado, rindo, quando, de repente, olha para seu relógio e, ao perceber as horas, assusta-se, saindo correndo pois já era muito tarde. Thomas ainda pergunta se vai vê-la de novo, demonstrando um interesse inusitado e inesperado por alguém, ao mesmo tempo que também parece não demostrar ter muita importância o fato de ela ter realmente decidido ir embora. Como veio, foi. Mais um gole no copo de vinho e volta ao trabalho, aparentemente a única coisa que lhe interessa de verdade.

Mas, mesmo aqui, naquilo que parece ser seu único interesse
${ }^{11} \mathrm{O}$ conceito de naturalismo que estamos utilizando refere-se à "construção de espaço cujo esforço se dá na direção de uma reprodução fiel das aparências imediatas do mundo físico (...)" (Xavier, 1984, p. 31). Não entraremos aqui na polêmica do realismo de Kracauer (1960) e Bazin (1985) por achar suas con-cepções mais distan-tes do que queremos ressaltar.

12 Não existem músicas inseridas neste filme com o sentido de colaborar na construção de sentidos ou de sentimentos. O som apenas parece acompanhar o som do que acontece na his-tória, os ruídos de seus ambientes. Nenhuma música que venha do nada. Nenhuma "trilha sonora". 
consistente, temos uma grande ambigüidade. Thomas aparece e sua postura o coloca no filme como um renomado fotógrafo de moda, ao qual todos devem se curvar. Curiosamente, ao mesmo tempo, passa quase todo o filme trabalhando nas fotos de seu livro, um ensaio fotográfico, que será, também, a razão de sua ida a parque e de "seu" testemunho de um crime. Mais um indício que parece querer nos dizer que temos aqui universos paralelos que precisam ser desvendados para que consigamos compreender os múltiplos significados que os vários caminhos da história constroem e nos propõem, como se estivéssemos nós mesmos perdidos no labirinto de Teseu.

Esta ruptura da única relação que aparentemente se constituiria, com o conseqüente desaparecimento definitivo da mulher, é mais uma história que se perde no fluxo geral dos acontecimentos que confluem para a trama geral que se desdobra no filme. Com isso, o que podemos ver é que a vida de Thomas se compõe de um fluxo de tempo absolutamente descontínuo, que emerge para nós (e para ele mesmo) nos momentos mais inusitados, levando a história ao seu sabor para direções cada vez mais inesperadas ${ }^{13}$. Quando algo parece estar finalmente para acontecer, quando a história parece ter encontrado seu caminho seguro, algo a faz mudar de direção e uma nova história, com sua temporalidade própria, dirige nosso olhar novamente para outro lugar diferente daqueles para os quais estávamos olhando. É como se Thomas fosse a entidade pela qual passa um feixe de outras histórias, cada uma com a sua dimensão própria, mas aparentemente incongruentes entre si, que se mostram em pedaços desconexos e episódicos aos nossos olhos, e que só podem e vão adquirir sentido por meio do fotógrafo, ao serem reinseridas em sua própria história, em sua própria busca. História esta, além de tudo, que não parece ter uma direção primordial, mas ser um emaranhado de fenômenos que só podem adquirir sentido se forem retirados de seu fluxo natural e (re)ordenados segundo outros parâmetros. Selecionar para compreender, selecionar para propor significados ${ }^{14}$. Não só para Thomas mas para nós também, perdidos que estamos sem saber em que direção devemos olhar para tentarmos compreender do que é que o filme realmente está falando, quais são realmente as questões que ele problematiza e sobre as quais devemos nos debruçar.

Será somente a partir da ampliação das fotos que ele tirou no parque naquela manhã que as coisas parecem começar a querer encontrar o seu fio da meada, pois aquele filme fotográfico, além de tudo, é duplamente revelador: num primeiro momento, revela-nos o que os olhos não viram; num segundo, desvela o que para nós deverá ser significativo nas imagens complexas que contemplamos. Thomas começa a ampliar as fotos, em tamanhos cada vez maiores. Ele está só, introspectivo, olhando com vagar as várias imagens que vai compondo, que vai pendurando lado a lado, tentando remontar sentidos possíveis de uma história perdida. São sempre imagens do parque, para as quais a sua atenção se volta sucessivamente, ressaltando o seu olhar sempre pensativo. Em si mesmas aquelas fotos contêm apenas isso: imagens plácidas de um parque semivazio. De repente, entretanto, algo lhe chama subitamente a atenção. Aproxima-se, olha para a foto em que o casal está de mãos dadas, em seguida para outra em que se abraçam, volta 
para a anterior, aproxima-se ainda mais, olha mais detalhadamente. Sua vista começa a selecionar, em cada foto, imperceptivelmente, o que lhe parece significativo. Ele amplia apenas um detalhe de uma delas, o casal que se abraça. Pode aí perceber, então, que a moça, enquanto o abraça, parece olhar assustada na direção de uns arbustos. Thomas retorna para a foto anterior, tentando recuperar o trajeto daquele olhar e o lugar para onde ele se deslocava. Mais um copo de vinho. Continua olhando para as fotos pois algo lá parece estar errado, algo o incomoda. Com uma grande lupa na mão, como Sherlock Holmes, ele marca um retângulo em algum lugar dos arbustos onde nós, espectadores, não vemos nada. Mais uma ampliação. Agora temos, lado a lado, em sua unicidade temporal e em sua descontinuidade espacial, a moça que olha e o arbusto que está sendo olhado. Podemos vislumbrar, a partir de sua atenção, algo que sem ela continuaria perdido no meio de um monte de informações desconexas e indecifráveis. É somente a curiosidade de seu olhar que detona em Thomas a capacidade de ver ali, onde não havia nada anteriormente, a imagem pressuposta de um pedaço de um rosto que os espreitava pelo meio dos arbustos.

Ele continua curioso, tentando compreender o que seriam aquelas coisas e onde levariam a sua percepção. Tenta obter ajuda, ao tentar ligar para a moça, mas percebe que isto é impossível, pois ela havia lhe deixado um número de telefone falso. Não adianta pedir ajuda, o significado deve sempre brotar de nós mesmos, sujeitos que somos dos sentidos que construímos em nossas relações de interação com os outros, por mais que tais significados estejam sempre dentro dos limites de universos culturais compartilhados. Thomas volta, preocupado, a olhar mais detalhadamente a imagem dos arbustos, sobre a cerca. Mais uma ampliação, só um pedaço da cerca. Mais uma seqüência de imagens se forma, um discurso se esboça. $\mathrm{O}$ casal distante de mãos dadas. De perto de mãos dadas. Abraçando-se ao longe. A ampliação deste abraço com o seu olhar assustado. $\mathrm{O}$ abraço mais longe de novo, o olhar voltado agora para os arbustos que escondem. $\mathrm{O}$ arbusto de perto para que possamos ver a imagem confusa do rosto que ali se esconde. Mais um recorte. Mais de perto, outra direção. Aparece agora uma mão que segura algo que parece ser uma arma. Neste momento começamos a escutar o som do vento nas árvores, como escutávamos no momento em que Thomas lá estava fotografando. Algo de muito importante está acontecendo. Na imagem e no sentido que elas agora parecem constituir com o olhar de nosso fotógrafo. Retorna novamente para o casal que olha. Para o rosto da moça que demonstra preocupação. Para o homem. Outro close nela. Depois, com a mão para a frente. Ela, ao fundo, parada perto de uma árvore. Uma ampliação dela parada de costas perto da árvore. Outra mais distante. Thomas olha para o lado tentando entender alguma coisa. Completa finalmente a história: ele evitou um crime. Agora, as coisas finalmente fazem sentido. Só que errado.

Ouve-se um barulho na porta, e por ela vão entrar aquelas duas jovens de roupas coloridas, para invadir e desviar novamente a sua, e a nossa, atenção.

O que precisamos é retirar do fluxo contínuo e incessante de 
${ }^{15}$ Bazin nos diz, em seu texto A ontologia da imagem fotográfica (Bazin, 1985, p. 9- 17), que as fotos são a expressão da possibilidade de se paralisar o tempo, um tempo subtraído de sua própria corrupção. Para que possamos perceber as fotos neste registro, teríamos de pensá-las como objetos dotados de significados próprios, independentes dos olhares que poderiam se debruçar sobre elas. Como Benjamin nos aponta (veja-se em especial Pequena história da fotografia, 1994b), os sentidos não estão nas fotos em si, mas nas relações que elas estabelecem com aqueles que as olham.

${ }^{16}$ Lembremo-nos aqui das palavras irônicas que Rembrandt dirigia aos seus críticos, quando estes diziam que seus quadros nada mais eram do que man-chas e borrões colo-ridos. Ele os alertava para não chegarem muito perto de suas telas com o nariz, pois o cheiro das tintas fa-talmente os intoxica-riam, numa clara alusão de que as imagens só podem adquirir sentido se não forem separadas do todo que as define como são e que lhes dá sentido. eventos que ocorrem e se superpõem sem parar, alguns momentos que, reordenados, podem assim adquirir algum significado. Não basta saber para onde olhar. É necessário reinterpretar o que se olha. E isto se realça, ainda mais, em virtude deste artifício curioso das imagens fotográficas, que quanto mais se permitem aproximar, quanto maiores ficam para nós, mais e mais nos fazem perder a precisão e a definição daquilo que nos é dado a olhar. Podemos olhar com mais detalhes, ao mesmo tempo em que estes mesmos detalhes negam a nitidez que os permitiria defini-los enquanto tal. Podemos ver mais, ao mesmo tempo em que vemos menos. Temos que saber ver, para identificar neste menos o significado que os olhos se esforçam em descortinar. Novamente vemos bits de informação, que só se transformarão em algo com significado se reunidos de uma maneira conveniente pelos olhos experientes, pelos olhos que aprenderam a ver, pelos olhos que investigam $^{15}$.

Nosso fotógrafo retorna para as fotos do mesmo jeito como as deixou. Enquanto lhe são colocadas as meias, ele muda completamente sua atenção, com o olhar fixo para aquelas imagens, para completo espanto das duas mocinhas que parecem não perceber a (não)conseqüência de sua pequena orgia, a inutilidade de seus esforços para assegurar os favores e as fotos de Thomas, pois sua atenção continua totalmente voltada para o mistério que o instiga. Com o olhar compenetrado, continua imerso nas imagens que aquelas fotos descortinam e em algo que teimam em não desvelar. Algo parece ainda estar fora do lugar. Mas, o que será que a sua intuição já percebeu antes mesmo que os seus olhos conseguissem descortinar? Thomas parece dar forma visual àquela velha frase de Nietzsche: "O pensamento se apresenta quando 'ele' quer, e não quando 'eu' quero" (Nietzsche, 1971, DPF \#17, p. 35). Novamente pega a lupa, mais ampliações, ainda maiores, cada vez grãos mais estourados, cada vez imagens menos nítidas, e cada vez mais prenhes de um possível significado. Um último recurso. Refotografar o pequeno pedaço de imagem para a qual os olhos se voltaram e no qual nada viram. Ou onde, quando viram, nada compreenderam. Apenas um detalhe superampliado. Manchas brancas e pretas que se alternam em uma pletora de informações, lembrando-nos dos quadros de Monet ${ }^{16}$. Thomas coloca, ao lado deste fragmento, uma outra foto com a imagem mais distante. E é somente agora, na encruzilhada visual destas duas imagens que em si mesmas pouco parecem significar, que ele, finalmente, pode dar-se conta do engano de sua primeira conclusão, da sua não compreensão inicial do que o jogo furtivo das imagens realmente lhe proporcionava. Seu rosto muda de expressão. Está agora aturdido com a súbita revelação daquilo que os seus olhos haviam se furtado a perceber. Quase que não acreditando na única coisa que para ele se coloca como palpável, suas próprias imagens, volta ao parque para confirmar com os olhos o que eles já descortinaram de uma outra forma. Vai ao parque para checar a realidade, para compará-la com a sua imagem, agora sua realidade primeira. Lá chegando vê o corpo, caído, de olhos abertos. Ajoelha-se e o toca, para ter certeza de que seus olhos não mentem. Olhos nos quais ele parece já não acreditar muito. Esta cena é poderosamente sintomática. Ele vai até o parque para ter certeza da 
imagem, para comprovar a sua veracidade, e não o contrário, pois a imagem é agora, na verdade, a sua realidade primeira. Curiosamente, Thomas nos aponta, avant la lettre, para um processo de inversão de referência entre coisa e imagem que irá se acentuar de maneira radical até este fim de século ${ }^{17}$.

Quando volta ao ateliê, todas as suas ampliações desapareceram. Está tudo revirado, tudo arrancado, tudo que estava por lá agora está sumido. Fotos, filmes, contatos, tudo. Por acaso, sempre o acaso, caída entre duas máquinas, resta uma única foto, a mais ampliada de todas, do corpo caído na grama. Ele se sente aliviado. Ou quase. Ao contar a história para a mulher do pintor, que ali acabava de entrar, as suas próprias palavras revelam a ambigüidade daquilo que para ele era uma verdade indelével. "Eu vi um homem morto esta manhã". E, ao ser perguntado como foi que isto havia acontecido ele responde: "Não sei, não vi", para seu próprio espanto. E é aí que justamente está o problema. O que foi que ele realmente viu? Rigorosamente falando, nada. $\mathrm{O}$ que ele conseguiu ver foram as imagens de um morto. Imagem que ele lhe mostra confiante dizendo que é o corpo. Ela olha para aquele papel, mas nada vê. Sem as outras referências, sem algo do qual partir para construir algum significado, aquilo que lhe é mostrado nada mais é do que um monte desconexo de pontos e manchas. Como é o mundo, um emaranhado de eventos que acontecem ao mesmo tempo e que, como tais, são inapreensíveis (cf. Weber, 1979). Um emaranhado de informações sem alguma ordem que lhes aporte algum significado. Um grande nada. "Parece uma das pinturas de Bill". Ele concorda, desolado. Que poderia fazer. Para ele tudo é tão claro. Como eram para Bill os seus quadros.

Para quem ainda não entendeu onde é que esta história quer nos levar, Antonioni nos brinda no final com a estranha, e aparentemente extemporânea, cena do concerto de rock. Tudo é muito estranho. É um rock violento, barulhento e agitado. O grupo, vestido com as suas roupas acetinadas, capricha em seu desempenho. Até que um dos amplificadores começa a falhar, para a irritação profunda do guitarrista que o utiliza. $\mathrm{O}$ público, que lota o ambiente, não se mexe, ouvindo tudo aquilo sem mover um músculo. Um ou outro mexe os olhos. O resto nada. Apenas um casal dança, meio deslocado, no meio daquela massa estática, além de estar completamente fora do ritmo. Em um dado momento, num acesso final de ira, o guitarrista começa a quebrar seu instrumento, transformando-o em pedaços, terminando por atirar o que restou do braço destruído bem no meio da platéia. Para espanto geral, aquela platéia apática agora entra em delírio. Gritaria, berros, luta ${ }^{18}$. Todo mundo querendo pegar aquele pedaço da guitarra de seu ídolo. Faz-se a maior confusão. Thomas consegue agarrar aquele braço e sai correndo com ele, sendo seguido por uma multidão que vai escasseando pouco a pouco. Ao chegar à rua, já sem ser perseguido, ele vira-se, olha, e joga o braço da guitarra tão ferozmente disputado no chão. Um rapaz que está ali do lado, ao ver o que aconteceu, caminha até aquele pedaço de madeira, pega-o, olha-o, e joga displicentemente no chão aquele braço de guitarra disputado de maneira tão feroz. Nada possui mais identidade
${ }^{17}$ Marcuse (s./d.) já nos apontava, em 1968, para esta complexa relação entre as imagens artísticas e a realidade. Baudrillard (1995, p. 17), levou isto às últimas conseqüências: "O único suspense que nos resta é o de saber até onde pode o mundo se desrealizar antes de sucumbir ao seu muito pouco de realidade..."

${ }^{18}$ É curioso perceber que a platéia que vê um show de um conjunto que existia na época (os Yardbirds), está praticamente paralisada até o mo-mento em que uma "imagem" daquela mesma cena, um duplo da banda que toca, cai no meio dela materializado em um braço de guitarra quebrado. É como se o real não causasse mais nenhuma reação nas pessoas, mas apenas as imagens, agora, suas realidades primeiras. 
${ }^{19}$ Não pensamos aqui este contexto como um contexto histórico mas como um contexto de referências que possibilitasse a proposição de alguma compreensão ou interpretação significativa.

${ }^{20} \mathrm{O}$ jogo de imagens aqui é tão interessante e rápido que temos dificuldade de perceber que os dois veículos continuam na mesma distância e sua aproximação é feita simplesmente por um zoom na traseira do caminhão.

21 Sobre as inúmeras diferenças entre o que os olhos vêem e os filmes mostram cf. Arnheim (s./d.), Carrière (1995), Bazin (1985), Sorlin (1977), Francastel (1983) e Kracauer (1960), entre outros. própria. Aquele braço é como as próprias fotos de Thomas, ou as pinturas de Bill. Se as retiramos do contexto em que adquirem sentido, nada mais são do que um pedaço de madeira quebrado, um monte de manchas, um monte de riscos, um monte de nada ${ }^{19}$. Sem qualquer significado intrínseco. É a relação com o nosso olhar que lhes dá significado. É o nosso olhar que lhes recoloca no fluxo do tempo, no fluxo do nosso tempo pois é a nossa memória que os transforma em alguma coisa que tenha sentido. Aqui se ressalta também um outro detalhe importante, como veremos mais à frente. Esta cena realça pela pseudopresença deste real os indícios incontornáveis de sua ausência. O real aparece aqui completamente desvalorizado, pois o que vale é o seu duplo expresso por meio de uma guitarra quebrada. É ele que faz "sentido" para a platéia que parecia adormecida pelo show. É ele (o duplo - a imagem) que faz com que todos aqueles que antes apenas olhavam saiam finalmente de sua compartilhada letargia.

Uma outra cena, que passa quase despercebida, mostra-nos, sob outras condições, quase a mesma coisa. Na primeira vez em que Thomas vai ao antiquário, ele aproxima o seu carro da traseira de um caminhão preto. A cena é rápida, confusa, e até nos causa um certo mal estar. Seu carro se aproxima ${ }^{20} \mathrm{e}$, no momento em que quase encosta na traseira do caminhão, Thomas o desvia para a direita visando ultrapassá-lo. Um prédio vermelho, que se ergue à sua frente, afasta-se de nós violentamente enquanto o carro continua indo para a frente o que faria com que aquele edifício, logicamente, aparecesse, ao contrário, cada vez mais perto. Com este jogo de zoom, muito mais rápido que a velocidade do próprio carro, Antonioni nos mostra como todas as imagens dependem de um referencial que lhes dêem sentido. No tempo, e no espaço.

Aqui se completa o curioso jogo de ilusões que o diretor constrói para nos mostrar que o que estamos vendo é um filme e não qualquer tipo de reprodução, representação ou clone do real. Como contraste ao naturalismo de sua diegese, sem nenhum som que possa se distinguir do som ambiente dos lugares que o filme mostra, Antonioni parece querer brincar com os espectadores ao propor a eles três momentos aparentemente heterodoxos em relação à linearidade de sua proposição fílmica. $\mathrm{O}$ primeiro deles, relativo à sua construção espacial, expressa-se na cena da ultrapassagem do caminhão preto, que parece uma cena incrustada num discurso do qual se distingue e no qual parece não ter sentido, pois em nada colabora para a compreensão daquilo que estamos vendo. Porém, ao montar a cena com esse jogo de zooms, o diretor cria um contraponto à naturalização das imagens que estamos assistindo pois, independente de todas as abstrações das descontinuidades de tempo e espaço que o espectador tem de fazer para "ver" no filme algo semelhante ao "real" 21 , movimentos como esses são impossíveis de serem vistos fora do mundo das imagens. O segundo momento é aquele no qual Thomas está investigando as imagens tiradas no parque por meio das ampliações que olha incessantemente, e no qual começa a escutar o farfalhar das árvores ao vento, e que se completa com a cena final do filme, da bola de tênis. O terceiro é o do show de rock, quando Antonioni introduz no filme um recorte do real e que contraditoriamente 
parece para nós espectadores como um dos momentos mais irreais do filme ${ }^{22}$. Como dissemos, esta cena só parece adquirir "cara de real" no momento em que uma imagem dela mesma entra em cena: o cabo quebrado da guitarra. Nestes três momentos, cada um com uma inserção diferenciada, Antonioni parece proceder como procediam Picasso e Braque em suas colagens, quando para contrapor à percepção de qualquer ilusionismo em suas telas acabavam por inserir nelas um pedaço verdadeiro do real (recorte de jornal, pedaço de tecido, areia, etc. ${ }^{23}$. Aqui, como lá, a inserção de um pedaço do real na imagem só pode reforçar a sua qualidade de imagem e não de real. Ao colocar na tela o real mostramos a todos que a tela é só isso: uma tela. Ao colocarmos no filme um conjunto personificando e atuando como a si mesmo, deixa-se claro que um filme é só isso: um filme, um conjunto de imagens, uma construção que tem como sua única e verdadeira realidade a realidade das imagens que nos mostra. Assim, Antonioni parece não querer nos deixar esquecer que a única realidade a que pode aspirar um filme é a sua própria realidade enquanto filme. Nada mais do que isso.

Voltando à nossa história, Thomas, por fim, não tem sorte em fazer com que alguém compartilhe a sua tão profunda descoberta. Ron, seu amigo e editor, com quem ele vai se encontrar na festa, está tão "chapado" - como vemos no momento em que se vira e sua mão segura dois "cigarros" - que nada compreende do que Thomas procura lhe contar.

Mas nosso fotógrafo não desiste. Ao amanhecer, munido novamente de sua câmera, ele retorna para o parque. O lugar é o mesmo, o barulho das árvores é o mesmo, mas o corpo não está mais lá. Bate a máquina no chão em sinal de profunda decepção, enquanto olha para todos os lados para certificar-se de estar mesmo no lugar certo. Checa todas as vistas com relação às fotos que

havia tirado - a escada, os arbustos, a cerca, o gramado. Não tem mais dúvidas, o lugar é aquele mesmo. Mas, o seu retorno até lá vai provar que na noite anterior ele não havia acreditado em seus próprios olhos. Thomas precisa da imagem da coisa e não da própria coisa para ter certeza. Para poder enfim acreditar, definitivamente e sem nenhuma dúvida, na realidade da imagem.

As cenas finais terminam o círculo que estamos percorrendo desde o início do filme ${ }^{24}$. Reaparece, nestas imagens, aquela mesma trupe de mímicos barulhentos. São tantas pessoas em cima de um jeep que isto por si só já seria curioso. Dois deles entram na quadra de tênis, enquanto o resto se transforma em platéia. Neste momento, e pela primeira vez, todos estão em silêncio. Os dois movimentam as mãos como se jogassem uma bolinha para cima. Colocam-se cada um de um lado da quadra e começam a jogar. Seus movimentos recuperam o movimento próprio do jogo, a disputa de um ponto, as batidas com as raquetes, os saques, os smashs. Thomas encostase em um dos cantos da quadra e observa tudo aquilo silencioso. A câmera se volta para os rostos da "platéia", que movimenta suas cabeças de um lado para o outro acompanhando o jogo e os movimentos daquela bolinha. Em um dado momento, a bola imaginária voa violentamente de encontro ao alambrado. Todos recuam assustados. O jogador pisca o olho e sorri. Pela

\footnotetext{
22 "Coincidências, eventos improváveis a verdade não é sempre convincente. Sempre soubemos disso. O cinema, que tão freqüentemente se aventura pelo irreal, constantemente renuncia a uma realidade que considera difícil de-mais de ser engolida" (Carrière, 1995, p. 87)

${ }^{23}$ Sobre as colagens cf. o interessante estudo de Peter Burger (1984).
} 
brincadeira. Um jogando, a outra jogando, a imagem gira pelo ar de um lado para o outro. Até que um deles erra feio a sua raquetada. Todos olham por sobre o alambrado, inclusive Thomas, inclusive nós. A câmera constrói este movimento e nos mostra uma imagem que desce e que desliza pela grama verde até ir parando bem devagar. Não há nada lá, mas nós vemos tudo. Ao ser recriado o movimento foi também recriado o objeto que o efetua. Mesmo que ele não esteja lá. Ou está? Thomas corre para o meio do gramado, abaixa-se, pega a bola(?) com a mão, joga-a duas vezes para cima e a atira de volta para a quadra. Podemos acompanhar o seu movimento (da bola) pelo movimento de seus olhos que a acompanham até o seu destino. Entrando finalmente no jogo, e completando o seu ciclo, continuamos a ver de perto o rosto de Thomas que volta a acompanhá-lo. Só que, neste momento, tanto Thomas como nós mesmos começamos também a ouvir o barulho da bolinha que pula de um lado para o outro da quadra.

Ao aceitar a realidade da imagem, Thomas acaba também por dissolver a separação entre real e imaginário, entre imagem da coisa e a coisa em si, que todos os indícios do filme já constituíam desde os seus primórdios. Thomas finalmente realiza o que já vinha realizando com os outros desde o começo do filme: uma inversão.

Não é incomum se associar a este filme a interpretação de que ele é um imenso discurso sobre a incomunicabilidade dos homens (cf. Kolker, 1983, p. 137-142; entre outros). Não nos parece, entretanto, que esta interpretação seja de fato apropriada. Propomos investigar as suas imagens em uma outra direção. Como vimos, Thomas comunica-se com todo mundo o tempo todo, até mesmo quando está dentro do carro. Ele está sempre se comunicando. O problema, portanto, está em outro lugar. O fato de ele se comunicar não quer dizer obrigatoriamente que ele será compreendido. Vimos exaustivamente como as suas comunicações parecem cair no vazio. O que vimos também foi que a verdadeira testemunha dos acontecimentos que o instigaram foi a sua máquina fotográfica e as imagens que ela nos portou, mediações necessárias para se ver alguma coisa nesta nova configuração do mundo.

Além disso, o show de rock nos mostra um outro caminho interpretativo possível. O problema não está, rigorosamente, na falta de comunicação ou na incomunicabilidade, como tantas vezes se falou, mas na mudança do referencial desta comunicação, das palavras e das coisas para as imagens destas mesmas coisas. $\mathrm{O}$ homem não olha mais para um real a partir do qual vai criar determinadas imagens e das quais ele seria o seu referencial primeiro. Agora, o homem olha primeiro as imagens para depois compará-las com algo que ainda possui o nome de "real" mas que não tem mais o mesmo estatuto de realidade que possuía anteriormente. Agora, o "real" serve para medir a perfeição da imagem e não o contrário. O que cria no mais das vezes a desqualificação mesma deste "real" em relação às imagens que se colocam em seu lugar, que adquirem aqui a capacidade concreta de aparecerem como realidades de imagem, finalmente como realidade primeira. É só por isso que ele volta para o parque com a máquina no dia seguinte. Para poder refazer as imagens nas quais acredita e que são 
a sua real medida de verdade. Verdade que só pode ser propriamente verdadeira por ser, e enquanto for, imagem. O problema crucial é saber se ainda existe alguma outra. Sua entrada física no jogo de tênis e o som da bolinha que a acompanha e que todos nós ouvimos parecem nos indicar que não, ao mesmo tempo que se exige de nós pelos nossos ouvidos a nossa insuspeita cumplicidade e aceitação. Pois afinal, não somos nós espectadores parte deste mesmo mundo que o filme descortina? Não somos nós mesmos que o construímos através de nossas relações e interações?

Podemos por fim entender o que de fato queria nos dizer o nome dado ao filme. Não o brasileiro, que não quer dizer absolutamente nada. Mas o original, em inglês, em um filme de um diretor italiano. Blow Up significa ampliar, ampliar fotografias em tamanhos enormes como vimos Thomas fazer aos montes. Mas significa também explodir, não só o grão fotográfico que se expande, até perder qualquer significado, mas, e principalmente, explodir as velhas referências que nos davam a medida e a orientação das coisas. Neste filme e, a partir dele, em todos os lugares, tudo acontece como se as pessoas só passassem a acreditar nas coisas que conseguem olhar enquanto imagens. Se não existe imagem, não existe a coisa, em uma curiosa inversão das palavras de Bazin a respeito do surgimento da fotografia: "a fotografia se beneficia de uma transferência de realidade da coisa para a sua reprodução" (Bazin, 1985, p. 14). Aqui, essa proposição aparece invertida. Agora, é a coisa que se beneficia de uma transferência advinda da realidade da imagem. Se antes medíamos a foto pelo modelo, agora medimos o modelo pela foto. Antonioni parece avançar na investigação do que seria o processo de disseminação das imagens, em grande parte ligado à expansão generalizada da televisão como meio de comunicação, que se daria primordialmente na década de 80 . A partir deste momento, antes de se conhecer qualquer coisa, conhecemos as imagens que existem e que se mostram sobre estas mesmas coisas ${ }^{25}$. É como se a partir de então o real tentasse cada vez mais se aproximar das imagens que dele se faziam e pelas quais passava a ser constantemente medido, e desvalorizado. Aqui, ao se colocar como lugar essencial de sua história aquele parque, situado naquele bairro londrino, fez-se uma analogia entre a própria renovação urbana e a renovação das formas de se olhar o que até então se concebia como "real". Em suas proposições, como também nas que Resnais deixará claro em Providence, real e imaginário ${ }^{26}$ não mais se distinguem um do outro (cf. Deleuze, 1986, p. 15). E se, como diz Virilio(1993), todas as guerras começam no imaginário, aqui, nos parece, que uma delas começou a ser ganha ${ }^{27}$, ao mesmo tempo que uma outra começava a ser perdida ${ }^{28}$.

Recebido para publicação em outubro/2000

\footnotetext{
${ }^{25}$ Em 1994, uma notícia no jornal $O$ Estado de S. Paulo dava-nos a dimensão trágica desta disseminação. Um garoto de 8 anos, sobrevivente de uma chacina na periferia da cidade, foi entrevistado pelo repórter que lhe perguntava o que é que ele tinha visto. Sua resposta foi exemplar: "na televisão, é muito mais bonito".

${ }^{26}$ Powell leva isto em outra direção. Contrapondo Real à Ilusão, chega a dizer que Thomas, ao pegar a bola, embarca na Ilusão. Devemos ressaltar que dissolver o real no imaginário é justamente arrebentar a separação que colocava estes dois conceitos como pólos opostos e não como momentos indiscerníveis de uma mes-ma relação.

${ }^{27}$ A da libertação sexual.

${ }^{28}$ A de que por aí se chegaria à revolução social.
} 
MENEZES, Pulo. Blow Up - images and mirages. Tempo Social; Rev. Sociol. USP, S. Paulo, 12(2): 15-35, November 2000.

ABSTRACT: This article analyses Blow Up, Michelangelo Antonioni's film, so as to understand how its visual discourse questions the relationship between the real and the imaginary. Behind a crime we know nothing about and will never know, the search carried out by the photographer reveals and questions the relationships between the images and the things whether photographs or films. He proposes meanings for their foundations and points of view, that set them apart from interpretations that see them as reproductions or representations of a a real presupposed as being whole and pre-existent .

\section{REFERÊNCIASBIBUOGRÁFICAS}

ARNHEIM, Rudolf. (s./d.) A arte do cinema. São Paulo, Martins Fontes.

ASHTON, D. (1985) Picasso on art. London, Thames and Hudson. Barcelona, Ediciones Omega.

BAUDRILLARD, Jean. (1995) Le crime parfait. Paris, Galilée.

BAZIN, André. (1985) Qu'est-ce que le cinéma ? Paris, Éditions du Cerf.

BENJAMIN, Walter. (1994a) Imagem de Proust. In: . Obras escolhidas - magia e técnica, arte e política. São Paulo, Brasiliense, p. 36-49.

. (1994b) Pequena história da fotografia. In: Obras escolhidas magia e técnica, arte e política: São Paulo, Brasiliense, p. 91107.

BURGER, Peter. (1984) Theory of avant-garde. Manchester, Manchester University Press.

CARRIÈRE, Jean-Claude. (1995) A linguagem secreta do cinema. Rio de Janeiro, Nova Fronteira.

DELEUZE, Giles. (1985) Image-temps. Paris, Éditions du Minuit.

FRANCASTEL, Pierre. (1983) Espace et ilusion; Les mécanismes de l'illusion filmique. In: . L'Image, la vision et l'imagination. Paris, Denoël Gonthier, p.167-206.

GOLDING, John. (1968) Le cubisme. Paris, René Juillard.

KOLKER, Robert Phillip. (1983) The altering eye. Contemporary international cinema. Oxford, Oxford University Press.

KRACAUER, Siegfried. (1960) Theory of film. Oxford, Oxford University Press.

LANGFORD, Michel. (1974) Iniciación a la fotografía profesional. 3a edição. 
MARCUSE, Herbert. (s./d.) Um ensaio para a libertação. Amadora, Livraria Bertrand.

MENEZES, Paulo. (1997) A trama das imagens. São Paulo, Edusp.

NIETZSCHE, Friedrich. (1971) Par-delà bien et mal. Textos e variantes organizados por Giorgio Colli e Mazzino Montinari. Trad. de Cornélius Heim. (DPF - Des préjugés des philosophes). Paris, Éditions Gallimard.

SIMMEL, Georg. (1983) Sociabilidade - um exemplo de sociologia pura ou formal. In: Moraes Filho, Evaristo de (org.). Simmel. Coleção Grandes Cientistas Sociais. Vol. 34. São Paulo, Ática.

SORLIN, Pierre. (1977) Sociologie du cinéma. Paris, Aubier Montaigne.

STANGOS, Nikos. (1981) Concepts of modern art. London, Thames and Hudson.

TARKOVSKI, Andrei. (1990) Esculpir o tempo. São Paulo, Martins Fontes.

VIRILIO, Paul. (1993) Guerra e cinema. São Paulo, Scritta.

VOGEL, Amos. (1974) Film as a subversive Art. New York, Randon House.

WEBER, Max. (1978) Ação e relação social. In: FORACCHI, Marialice encarini \&

MARTINS, José de Souza. Sociologia e Sociedade. Rio de Janeiro, LTC. . (1979) A “objetividade” do conhecimento nas Ciências Sociais. In: COHN, Gabriel (org.). Weber. Coleção Grandes Cientistas Sociais. Vol. 13. São Paulo, Ática, p. 79-127.

XAVIER, Ismail. (1984) O discurso cinematográfico. São Paulo, Paz e Terra. 